\title{
THE TAXONOMIC STATUS AND BIOGEOGRAPHIC SIGNIFICANCE OF THE SUMATRAN FORMICA (FORMICIDAE, HYMENOPTERA)*
}

\author{
BY ANDRÉ FRANCOEUR \\ Département des Sciences Pures, Université \\ du Québec à Chicoutimi, Québec, Canada \\ G7H 2B1
}

In a paper on the occurrence of Formica fusca in Sumatra, W. M. Wheeler (1927) erected the variety fairchildi for 12 workers collected above Kota Dah at an altitude of 4,000 feet in a pine forest. It has never been found again as far as I know. The examination of 10 of these specimens located in 3 different U.S. museums revealed a surprising similarity with Formica glacialis, a name that $I$ have recently resurrected in a taxonomic revision of the nearctic species belonging to the Formica fusca group (Francoeur, 1973). I compared workers of $F$. fairchildi to $F$. glacialis types and topotypes collected by me at South Harpswell, Maine, and no significant difference was noted. All the above specimens meet very well my description of the $F$. glacialis worker. Therefore the formal synonymy is:

\section{Formica glacialis}

Formica fusca var. glacialis Wheeler, 1908, Bull. Amer. Mus. Nat. History 24: 624, worker, female, male.

Formica fusca fusca: Wheeler (in part), 1913, Bull. Mus. Comp. Zool. Harvard 53: 494-497.

Formica fusca: Creighton (in part), 1950, Bull. Mus. Comp. Zool. Harvard 104: 532.

Formica glacialis: Francoeur, 1973, Mémoire Soc. Ent. Québec 3: 152-161.

Formica fusca var. fairchildi Wheeler, 1927, Psyche 34: 40-41, worker. Lectotype in MCZ, paratypes in AMNH, MCZ, USNM. NEW SYNONYMY.

This new synonymy eliminates the concept of a distinctive form of Formica in the southern half of the Oriental region. The presence of the genus in northern Sumatra perhaps may now be considered as an unexplained introduction rather than a tropical relict as reinterpreted by Gregg (1969) from Wheeler (1927). However,

*Manuscript received by the editor August 11, 1977 
the possibility might be considered that the Kota Dah Formica sample represents a labelling error, or the misplacement of a vial with North American ants in the Fairchild collecting kit. Such explanation seems much more likely than any introduction of Formica glacialis live into Sumatra. Other examples of this sort of mishap are very common in the Wheeler collection. In papers published in 1922 and 1927, Wheeler reported and discussed a similar case for the Philippines.

With this puzzling case once solved, the natural geographic distribution of the genus Formica appears to be entirely holarctic. Biogeographic boundaries of course do not follow straight lines; rather, they reflect topography and other factors affecting climate. Mountain ranges carry holarctic elements southward toward and into the tropics in both the Old World and the New. Thus the presence of Formica species in the high mountains of Taiwan and Burma is not surprising, since these ranges are nearby outliers or direct continuations of the holarctic uplands of mainland Asia. The range of the genus includes also the high elevations of central Mexico, in North America.

Nevertheless, that Formica could at one time have had a much wider or somewhat different distribution can still be supported by its richness, greater than previously recognized, in living species in the southern half of the Holarctic region, and by the presence of fossil Formica among numerous other subtropical and warm temperate insects found in the Baltic Amber of Oligocene age.

\section{ACKNOWLEDGEMENTS}

I am indebted to Mrs. Favreau, American Museum of Natural History, New York, H. E. Evans, Museum of Comparative Zoology, Harvard University, and D. R. Smith, U.S. National Museum, Washington, for loan of specimens. E. O. Wilson and W. L. Brown have my thanks for critically revising the manuscript. Research supported by National Research Council of Canada Grant A6501.

\section{REFERENCES}

GREGG, R. E.

1969. Geographic distribution of the ant genus Formica (Hymenoptera: Formicidae). Proc. Ent. Soc. Washington 71(1): 38-49.

WHEELER, W. M.

1922. Ants of the genus Formica in the Tropics. Psyche 29: 174-177. 

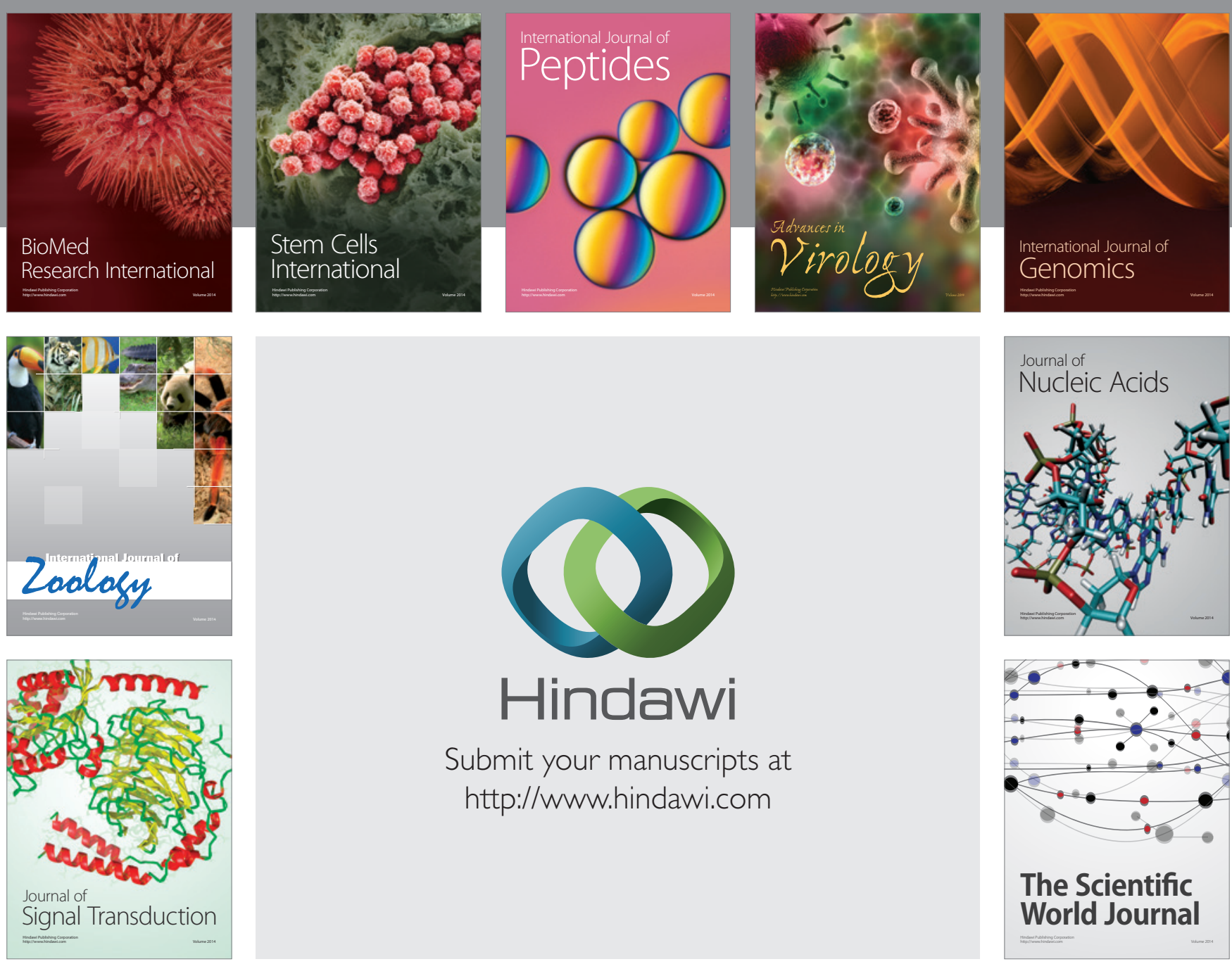

Submit your manuscripts at

http://www.hindawi.com
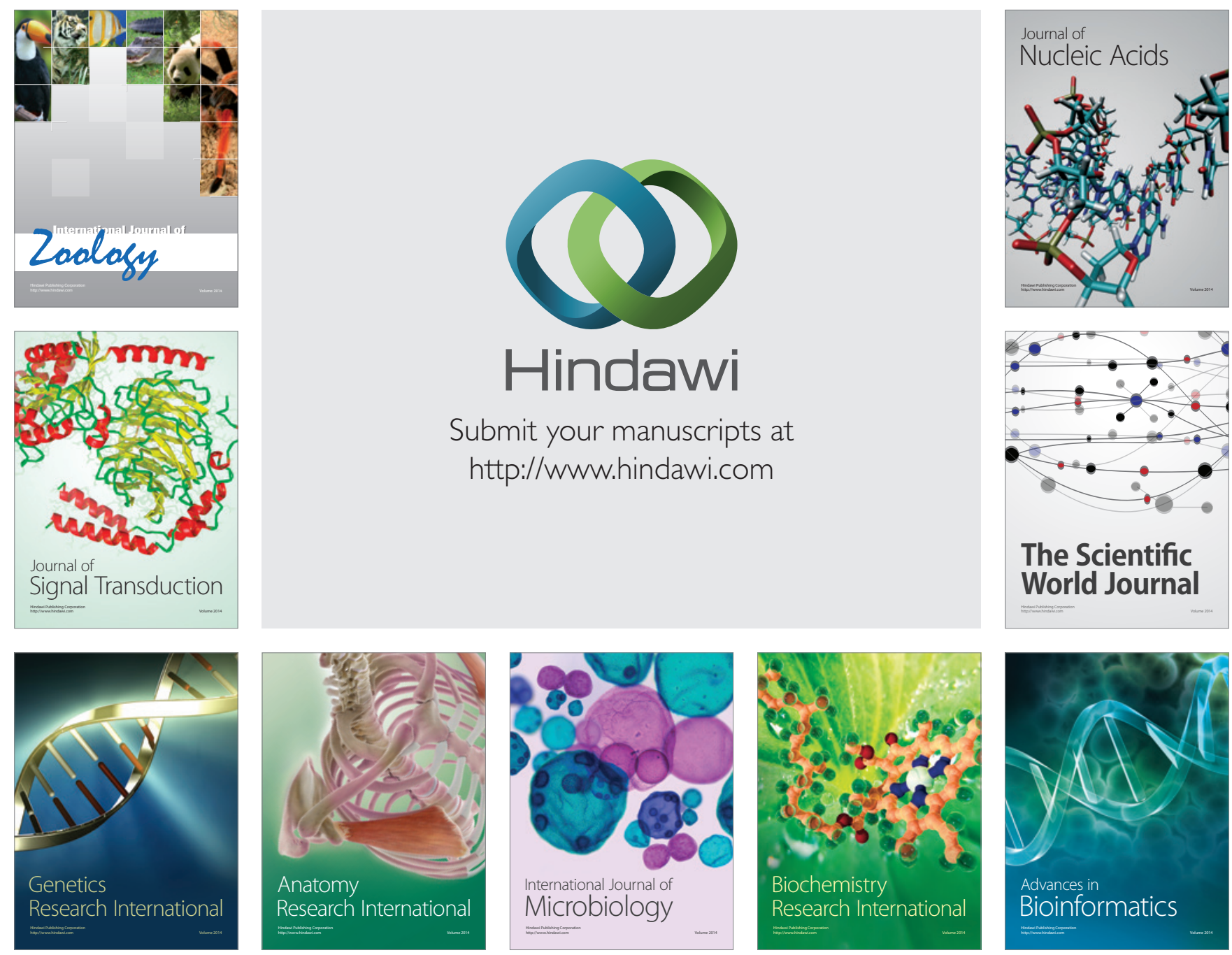

The Scientific World Journal
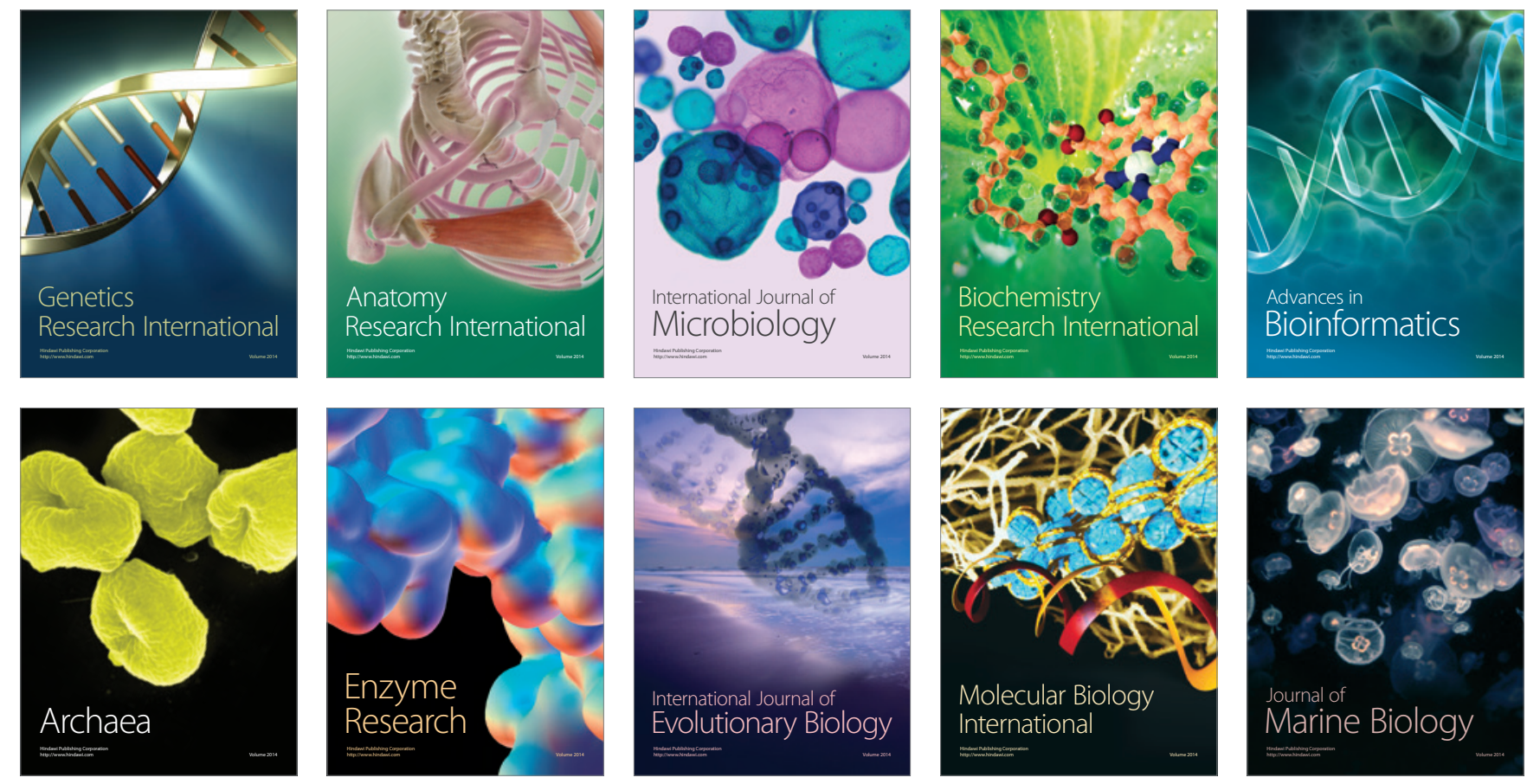